\title{
IDOLATRY AND FAITH: THE JURISPRUDENCE OF SANFORD LEVINSON
}

\author{
Jack M. Balkin*
}

\section{INTRODUCTION}

It is a great pleasure to be able to honor Sandy Levinson, my very dear friend, who has done so many things for me in the course of my academic life. He discovered me, when I was an assistant professor toiling in the vineyards at the University of MissouriKansas City, and he and Scot Powe persuaded the members of the faculty at the University of Texas School of Law to bring me there, and give me a job, perhaps against their better judgment. He was incredibly generous to me during my years there, and since then. He took me under his wing, and I learned an enormous amount from him, so much so, that as I describe the themes of his work to you in this essay, it strikes me how much these same themes have also become central to my own work as well. That is the depth and significance of his influence.

Of the many things he has done for me in the course of my academic career, one of the most valuable is allowing me the opportunity to collaborate with him. We have now written eleven articles, two books, and we are currently working on a third. But the greatest treasure he has given me is the gift of his friendship, which surpasses all, and I am deeply honored to be able to tell you about the work of this wonderful man, who I respect and admire greatly, and who I feel privileged every day of my life to be able to work with.

This essay is about the themes of Sandy's work, and what they mean to me. Anyone who reads Sandy's work knows that his interests are wide-ranging indeed. He has written about a large number of different topics, including constitutional law, professional responsibility, political theory, law and religion, multiculturalism, the study of public monuments, jurisprudence, interpretive theory, law and literature, and law and music, just to name a few. I cannot do justice to all of these themes in this essay. Rather, I will pick and choose among them, emphasizing the ones that have had the most influence on my own thought, and no doubt, I will end up articulating and embellishing them in ways that differ from the way Sandy would present them. But that, of course, is both the bounty and the price of influence. Influence means that what you think and say

* Knight Professor of Constitutional Law and the First Amendment, Yale Law School. My thanks to Mark Graber, Sanford Levinson, and Frank Michelman for their comments on previous versions of this essay. 
gets thought and said by others, but not necessarily the same way you would say it or think it.

Sandy is not a system builder in the Hegelian style. He is less architect than explorer, continually trying out new ideas, and testing old ones. He is at heart an essayist, happiest when he is offering analytical gems in a relatively few pages. He looks at an area and sees tensions and comparisons that no one had seen before. He asks other scholars: "If you are really committed to position A, then how do you explain your commitment to position B, and wouldn't you also have to think $\mathrm{C}$ as well?" Through the use of a dialectical method, he has been able to create an enormously rich set of problems and possibilities.

Like Socrates, Sandy Levinson offers little in the way of dogma or doctrine, but he stimulates everyone around him to rethink their position. This is, I think, one of the great sources of his influence. Many of his articles have titles like "Reflections on X," or "Thoughts about Y," or even "Comments about Z." " Such modesty might lead one to believe that his work lacks an overarching set of themes. But nothing could be further from the truth. There is a passage in Emerson - one of Sandy's favorite authors-in which Emerson compares a person to an Alexandrian sonnet. Like the Alexandrian sonnet, it does not matter whether you read it forwards or backwards, the nature of a person's true beliefs will shine through. ${ }^{2}$ And so it is with Sandy's work, which, if carefully read, reveals a consistent set of themes and problems that have fascinated him throughout his long and influential career.

\section{ACTS OF FAITH}

The most central theme in Sandy's work is faith. That word appears, appropriately enough, in the title of his first and most well-known book, Constitutional Faith. ${ }^{3}$ Sandy is a self-described secular Jew, an agnostic who nevertheless maintains a kosher home. This is, I think, a remarkable fact. After all, to keep kosher is a serious commitment, not only of one's time and energy, but, perhaps more importantly, of one's stomach. Sandy does not obey the laws of kashrut out of faith in God; he is agnostic about God's

1. See e.g. Sanford Levinson, "Democracy in a New America": Some Reflections on a Title, 79 N.C. L. Rev. 1559 (2001); Sanford Levinson, Structuring Intimacy: Some Reflections on the Fact That the Law Generally Does Not Protect Us against Unwanted Gazes, 89 Geo. L.J. 2073 (2001); Sanford Levinson, Some (Brief) Reflections about Law and Literature, 10 Cardozo Stud. L. \& Literature 121 (1998); Sanford Levinson, Constitutional Imperfection, Judicial Misinterpretation, and the Politics of Constitutional Amendment: Thoughts Generated by Some Current Proposals to Amend the Constitution, 1996 BYU L. Rev. 611; Sanford Levinson, Allocating Honor and Acting Honorably: Some Reflections Provoked by the Cardozo Conference on Slavery, 17 Cardozo L. Rev. 1969 (1996); Sanford Levinson, Hopwood: Some Reflections on Constitutional Interpretation by an Inferior Court, 2 Tex. Forum Civ. Liberties \& Civ. R. 113 (1996); Sanford Levinson, They Whisper: Reflections on Flags, Monuments, and State Holidays, and the Construction of Social Meaning in a Multicultural Society, 70 Chi.-Kent. L. Rev. 1079 (1995); Sanford Levinson, Identifying the Jewish Lawyer: Reflections on the Construction of Professional Identity, 14 Cardozo L. Rev. 1577 (1993); Sanford Levinson, Electoral Regulation: Some Comments, 18 Hofstra L. Rev. 411 (1989); Sanford Levinson, Some Reflections on the Posnerian Constitution, 56 Geo. Wash. L. Rev. 39 (1987); Sanford Levinson, Constituting Communities through Words That Bind: Reflections on Loyalty Oaths, 84 Mich. L. Rev. 1440 (1986). For an explanation of why it was important to give so many examples illustrating this point, see J.M. Balkin \& Sanford Levinson, How to Win Cites and Influence People, 71 Chi.-Kent. L. Rev. 843, 856 (1996) (Maxim Seven).

2. "A character is like an acrostic or Alexandrian stanza;- read it forward, backward, or across, it still spells the same thing." Ralph Waldo Emerson, Self Reliance (Henry Altemus Co. 1896).

3. Sanford Levinson, Constitutional Faith (Princenton U. Press 1988). 
existence. He does so because he is deeply devoted to his Judaism. The tension or the frisson between being agnostic about God, and nevertheless making the very considerable commitment to keeping kosher is a useful way of understanding what Sandy is about, and why faith is the central theme of his work.

Despite his agnosticism, Sandy remains a religious thinker. I think it is fair to say that Judaism inflects and influences all of Sandy's academic work. Not all aspects of Judaism, of course, for belief in one God is, after all, the central tenet of the Jewish religion. Rather, I identify Sandy particularly with that part of the Jewish tradition that is dialectical, devoted to conversation and intellectual exchange, focuses on the problems of interpretation and knowing truth, avoids closure, and is, on occasion, dizzyingly selfreflexive and even self-undermining. These are all parts of the Jewish tradition, even if they are surely not the whole; one can find them in the commentatorial tradition of the Talmud and the Midrash. ${ }^{4}$ They are all reflected in Sandy's approach.

Faith, of course, has many different aspects, and one can have faith in many different sorts of things: besides faith in God, one can also have faith in the law, faith in the Constitution, faith in the nation, or faith in the American people. For Sandy, faith is valuable and even desirable, but it is, at the same time, something fraught and deeply complicated. This dual attitude toward faith - his embrace of the value of faith and his critical attitude toward faith-is a central element of Sandy's work. Faith is always weighted by consequence, not only by the demands of the present but by the memory of the past and what has been done in the name of faith, whether it be faith in a particular religion, faith in the Rule of Law, or faith in the Constitution. Faith is not something that one simply has. It is something that one is immersed in, involved in, embedded in, responsible for. Faith is not simple or easy. It is something that one must think about, and worry about, and talk about, and discuss. Faith is the occasion for conversation and reflection, not the end of conversation and reflection. Faith does not substitute for or displace reason. It is both the nourishing spring and the critical object of reason.

Having faith is only the beginning of the inquiry. What exactly is it that you believe in? What is the ground of your faith? What justifies your faith? How do you know that you have faith? How do you show that you have faith? The demonstration of faith may be deeply tied to the possession of faith; often one acts to demonstrate that one believes, and in so acting, one confirms one's beliefs, both to others, and more importantly to one's self. Conversely, if one cannot demonstrate belief through action, the question remains whether one's faith is real or feigned, whether it is a genuine commitment or a set of beliefs retained out of inertia or convenience.

The key moment in Constitutional Faith occurs near the end of the book, when Sandy visits an exhibit sponsored by the National Park Service in Philadelphia during the Constitution's Bicentennial. ${ }^{5}$ The exhibit invites people to add their names to the Constitution, and Sandy debates whether or not to sign the Constitution himself. Here is the issue of faith, crystallized in a single act, a single situation, asking him whether he is committed or not committed. But of course, it is not as simple as that. Signing the

4. See id. at 20 (quoting Gershom Scholem, The Messianic Idea in Judaism and Other Essays on Jewish Spirituality 290 (Schocken Books 1971)).

5. Id. at $180-94$. 
document in 1988 is hardly the same thing as signing it in 1787, or even, for that matter, 1861 , as the Union is dissolving into civil war. Moreover, both the signing and the refusal to sign might involve a commitment, just different types of commitment. Indeed, to refuse publicly to sign the Constitution - in the face of the self-congratulatory celebration of the Constitution's bicentennial - may be a more stringent or daring statement of commitment. Both the signing and the refusing to sign are acts of faith, but faith in different things. Both are also, interestingly, acts that might indicate lack of faith, but once again in different ways. Refusing to sign clearly suggests lack of faith in the constitutional enterprise. But signing might also indicate lack of faith that the country could survive without the compromises made in 1787.

It is not surprising, then, that oaths play a prominent role in Sandy's work. ${ }^{6}$ Taking an oath - especially in public, before an audience - is a time honored method of demonstrating one's commitments, both to others, and, equally importantly, to one's self. But Sandy is equally concerned with the puzzling character of oathtaking. To swear to defend the Constitution of the United States may not, he points out, necessarily commit a person to any particular substantive set of beliefs. ${ }^{7}$ It may not bind a person to behave in ways that people who insist on the oath might like. Presidents take an oath to obey the Constitution, but this may not constrain their actions, at least from the perspective of outside observers. Abraham Lincoln swore an oath to protect and defend the Constitution of the United States, as did Richard Nixon, but to this day many people still debate whether Lincoln's acts as President were consistent with the Constitution, and most people agree that several of Nixon's actions subverted the constitutional system. Conversely, refusing to take an oath, particularly when it is done in public, may crystallize a person's beliefs. Equally importantly, it strongly signals to outside observers what that person's views might be, perhaps even more strongly than the perfunctory or desultory swearing of oaths that many individuals engage in when they apply for licenses or other government benefits.

One of Sandy's favorite cases, United States v. Schneiderman, ${ }^{8}$ exemplifies the puzzles of public oaths and oathtaking. Schneiderman concerns whether a committed Communist can swear an oath to uphold the Constitution of the United States. The answer to that question, in turn, depends on a further set of questions about what it means to be committed to the Constitution, and ultimately, about what the Constitution is. Schneiderman, the Court ultimately held, could swear to uphold the Constitution even though he believed in the necessity of communism sweeping the globe, because, presumably, he could imagine the Constitution being peacefully altered or amended to enforce communist principles. ${ }^{9}$ Yet such a Constitution would be very different from the one we now possess.

Schneiderman is a difficult case because of the connections between faith and commitment. Normally, faith in something commits us to a view about the nature of what we have faith in, either what the object of faith is, or, in some versions of theology,

6. Id. at $90-121$

7. Id. at $123-26$.

8. 320 U.S. 118 (1943).

9. Levinson supra n. 3, at 137; Schneiderman, 320 U.S. at 137-38. 
what the object of faith is not. In some religious traditions, for example, to have faith in God is to believe something about God; that He made Heaven and Earth, that He is good, that $\mathrm{He}$ is omnipotent, that $\mathrm{He}$ has or desires to have a relationship with us, and so on. Yet if Schneiderman and a member of the John Birch Society could both swear an oath to protect and defend the Constitution, it is unclear what commitment to the Constitution really means. It is sort of like the joke about the politician who tried unsuccessfully to soothe religious tensions by reminding the audience that "It doesn't matter whether you are a Christian or a Jew, an agnostic or an atheist. Despite our differences, we all worship the same God."

By the end of Constitutional Faith, Sandy suggests that commitment to the Constitution is commitment to an open and continuing dialogue about what democratic self-government means. ${ }^{10}$ But at the same time, he acknowledges that this cannot be the whole story, for commitment to conversation and dialogue only begs the question: Dialogue on whose terms? No one would confuse the institutions of the United States Constitution with a Habermasian ideal speech situation. If the grounds of dialogue and participation are skewed in important ways - for example, if the rules of dialogue and the processes of self-governance are tilted toward the protection of the rich and the powerful - the Constitution may never become what Sandy hopes it will someday be.

\section{THE DANGERS OF LEGAL FAITH: THEODICY}

For Sandy, then, faith is the central jurisprudential question, linked to many central questions in law as well as in theology. Yet faith is not a simple matter; it is convoluted and perplexing, tangled and fraught. Faith is something desperately to be sought for and simultaneously something to be feared. Why is faith something to be feared? Because faith, although marvelous and beneficent, also holds hidden dangers.

The dangers of faith do not arise from the inevitable doubts that lead people to agnosticism or atheism, for those doubts lead people away from faith, not toward it. They arise because even the faithful, even the person who believes in God fervently and devotedly, knows that the works of religion, the products of religion, the practices and conventions of religion, are made by mortal human beings, by communities of belief that extend and evolve over time, sometimes over many centuries. They are not God's own creation; they are created by human beings in order to know and honor God. They are human representations of God's word; human attempts to know God and understand His ways. Because the practices and conventions of faith are the creations of mortal human beings, there is always the possibility of separation, distancing, or falling away from God. The conventions may be mistaken, the dogmas may become hardened and inflexible, the church and its leaders may become impious and corrupted. So even the most devoted face the dangers inherent in faith, and they face them not because they are agnostic but precisely because they have given their lives over to faith.

What are the dangers of faith? They are apology or theodicy on the one hand, and idolatry on the other. Theodicy is the more neutral term; apology is the more pejorative term. Apology is the delusion, conveyed to others, that what one believes in and is

10. Levinson, supra n. 3, at 193. 
committed to is good or righteous, or, in the fullness of time, will be revealed as good and righteous or become so. One apologizes for evil and injustice to make it appear acceptable and justified. Theodicy, of course, is the attempt to explain the existence of evil in a world with a good and omnipotent God.

From the standpoint of law, the question is whether belief in the Rule of Law (or, somewhat differently, in the Constitution) is what E.P. Thompson called "an unqualified human good," 11 or whether such faith might ultimately be a form of apology for the kinds of oppression and injustice that are wrought through the forms and practices, the technical arguments and devices of law and lawyering. Law can be a concretization of great human ideals, a realization of deep human aspirations. But it can also be a means through which the strong oppress the weak, and the unjust take advantage of the just. The problem is that law is both of these things at one and the same time.

When one believes in or has faith in the Rule of Law, or the United States Constitution, what exactly is it that one believes in? What exactly is it that one has faith in? One possibility is that one believes that the legal system, or the Constitution, are in fact just, or at least acceptably so. The theological analogy is belief that the world is in fact just. The belief that the world is just is hard to maintain in the face of the many evils in the world, and this fact gives rise to the need for theodicy. In like fashion, belief that the legal system is just is undermined when one comes face to face with the forms of injustice and wickedness practiced through human law. In theology, one can argue that the gift of free will makes the world better than it would be otherwise. Or one can argue that the path of human development is fated toward progress, or points inevitably toward a central event, like the coming of the Messiah or the Second Coming of Jesus, after which all will be properly resolved and an era of peace will reign.

There are analogous moves available with respect to law. One can justify one's faith in law, or in the Constitution, through a narrative of progress. Even though injustice and oppression are everywhere and have still not been wiped out, even though law and the forms of law are still abused and misused, both cynically and sanctimoniously, ultimately our faith, our commitment to the Rule of Law (or to the United States Constitution), will pay off. Past injustices will be rectified in the future; oppression through law in the present will give way to better, fairer practices in days yet to come. One's belief and faith in law, and in the Constitution, will ultimately be vindicated, and so it will have been worth it all along to have believed, to have had faith.

The philosophical theory called positivism denies that law must necessarily be just in order to be law. It is premised on the possibility of unjust laws. But positivism does not deny that law can be just, or be made just. So a positivist could have faith in a narrative of legal progress. Indeed, it is likely that many positivists have faith that law can and will become better, in part through the very forms of critique that positivism makes available. They believe that commitment to the political ideal of the Rule of Law will, in time, have a salutary effect that will justify or vindicate their faith in law, even though they acknowledge that many legal systems around the world are not particularly just.

11. E.P. Thompson, Whigs and Hunters: The Origin of the Black Act 266 (Pantheon Books 1975). 
I have been speaking of faith both in the Constitution and in the Rule of Law, but the two are of course distinct, and the grounds of faith in the two are also distinct, or may become distinct. It is surely possible to have faith in the Constitution, but not in the Rule of Law, depending on how thick or thin one's conception of the Rule of Law is. A thin conception would require only that such rules as exist be applied fairly and impartially to all, regardless of wealth or social status. A thicker conception might demand certain procedures for law to be created and applied, and a still thicker conception would begin to import some of the requirements of democracy and human rights that we find articulated in the United States Constitution. Faith in a very thin conception might not justify faith in eventual improvement; for laws can still be quite unjust even if they are applied impartially. And even in thicker conceptions, there is always more to justice than adherence to the Rule of Law.

Even if one does not put one's faith in the Rule of Law, however, one might still have faith that the particular set of legal institutions called the American Constitution are destined to work themselves pure over time. The evidence for this faith would be the fact that a country founded by rich white males, many of whom owned slaves and believed in natural hierarchies of race, class, and sex, eventually gave way to a more democratic nation that welcomed working men, blacks, and women to full and equal citizenship, and eventually secured basic rights and privileges after years of struggle. This familiar story of America and its Constitution I call the Great Progressive Narrative. $^{12}$ The Great Progressive Narrative, while not denying the inequities of the past, explains how we have gradually worked ourselves free of them: America has gotten freer, more equal, and more just, and it is still on that righteous path. It is yet to become what it will someday be. As Langston Hughes put it, with equal measures of accusation and hope, "America never was America to me, And yet I swear this oath-America will be!"13 America, the Great Progressive Narrative tells us, is still in a state of becomingit is still on the road to becoming America. And the American Constitution is a central document in that redemption. The Great Progressive Narrative is a theodicy that seeks to explain and excuse our past injustices: it is a narrative of faith in human progress organized around Americans' love of their Constitution and the principles that it embodies.

When one has faith in the Constitution in this way, one also has faith in the American nation, in the American people, as a people who will, through strife and struggle, eventually listen to what Abraham Lincoln called "the better angels of our nature," 14 and eventually make progress toward justice. That point is important, for belief in the Rule of Law is often opposed to belief in the Rule of Persons. But faith in the Constitution may well be faith, not simply in law, but in the ultimate goodness of a nation, or of a people.

12. Jack M. Balkin, Brown v. Board of Education: A Critical Introduction, in What Brown v. Board of Education Should Have Said: The Nation's Top Legal Experts Rewrite America's Landmark Civil Rights Decision 1, 5 (Jack M. Balkin ed., N.Y. U. Press 2001).

13. Langston Hughes, "Let America Be America Again," in America in Poetry: With Paintings, Drawings, Photographs and Other Works of Art 182, 185 (Charles Sullivan ed., Harry N. Abrams, Inc. 1988).

14. Abraham Lincoln, Speeches and Writings 1859-186: Speeches, Letters, and Miscellaneous Writing: Presidential Messages and Proclamations 224 (Viking Press 1989). 
For Sandy, these issues are crystallized in a simple question: Is the Constitution a comedy or a tragedy? ${ }^{15}$ If the Constitution is a comedy, then like a comedy it has a happy ending. Justice is served, either now or in the future. Often when Sandy asks this question, he means to ask it about the present: Does the best interpretation of the Constitution lead to a just result in the present $?^{16}$ But I think one can ask the same question about the progress of the Constitution over time. One can ask whether, in the long run, the development of the Constitution will lead us to a better, more just society, even though the Constitution currently permits and even requires some very serious injustices. If the Constitution is a comedy, then eventually our faith in the Constitution, and its development through democratic processes, will have paid off. And because our faith will have paid off, it made sense to have had faith all along. It was worth it for those at the bottom to suffer the injustices and indignities of the past because of the payoff at the end. If, on the other hand, the Constitution is a tragedy, we should not be surprised that adherence to the Constitution leads to injustice and oppression, nor should we be surprised that our grand national experiment in self-governance leads to tyranny, violence, or dissolution. If the Constitution is a tragedy, then we were engaged in apology when we downplayed its shortcomings. This was a theodicy we never should have engaged in.

A key figure in Sandy's work is William Lloyd Garrison, the militant abolitionist, who argued that protection of slavery in the 1787 Constitution was its fatal flaw. He argued that the Constitution was a "covenant with death, and an agreement with hell,"17 and that whether or not the South wanted to secede from the North, the North should secede from the South, for there should be no union with slaveholders. Even after slavery has been abolished, Garrison's accusation still haunts us today. Is the Constitution still, in some ways, a compromise with injustice, a pact with death, an agreement with hell?

Garrison's accusation brings home the connection between faith in the Constitution and the problem of theodicy or apology. Imagine once again the moment when the Framers sign the Constitution in Philadelphia, or the moment, two hundred years later, when Sandy stands in the museum in the same city, deciding whether to sign the Constitution or not. To sign the Constitution is to say to one's self, and to others: "It will work out, I believe it. Even though slavery is protected by the 1787 Constitution, and even though the Constitution as we know it today contains many injustices, I believe that the story of the Constitution is a comedy, not a tragedy. I believe that things will turn out for the best. I believe that the justice of the Constitutional system will be unveiled

15. Levinson, supra n. 3, at 59 ("Little recognition is given to the possibility that life under even the American Constitution may be a tragedy, presenting irresolvable conflicts between the realms of law and morality."); see Paul Brest, Sanford Levinson, J.M. Balkin \& Akhil Reed Amar, Processes of Constitutional Decisionmaking: Cases and Materials 114-17 (4th ed., Aspen L. \& Bus. 2000); J.M. Balkin, Agreements with Hell and Other Objects of Our Faith, 65 Fordham L. Rev. 1703, 1722-23 (1997).

16. See the collection of essays edited with Bill Eskridge, Constitutional Stupidities, Constitutional Tragedies (William N. Eskridge, Jr., \& Sanford Levinson eds., N.Y. U. Press 1998).

17. The phrase comes from a resolution Garrison introduced before the Massachusetts Anti-Slavery Society in 1843: "That the compact which exists between the North and South is 'a covenant with death, and an agreement with hell'-involving both parties in atrocious criminality; and should be immediately annulled." Walter M. Merrill, Against Wind and Tide: A Biography of Wm. Lloyd Garrison 205 (Harv. U. Press 1963). 
through history, and I am committed to working for its eventual vindication." Garrison clearly would not have signed. He believed that the Constitution was not just a tragedy in the long run; he believed that it was a tragedy in his own time. ${ }^{18}$

\section{THE DANGERS OF Legal FAITH: IDOLATRY}

The first danger of faith is the danger of apology or theodicy. The second danger of faith is the danger of idolatry. What is idolatry? Idolatry is the belief in a false god, in a graven image, in a false representation that purports to be the image of God but is not. The Second Commandment says that one must not worship a graven image. It is a central tenet of Judaism. Indeed, we might define Judaism as the religion that believes that one should never bow down before idols.

Sandy's jurisprudence is Judaic in this sense, for he believes, as I do, that one should never bow down before a graven image, either in one's religious practices, or in the law. And when one discovers idolatry, whether in the world or in the law, it is one's moral duty to denounce it.

What are the idols that exist in the world of law and in the world of the Constitution? There is the idolatry of the Rule of Law itself when viewed as a substitute for justice, the idolatry of legal reason as a solution to all moral and social problems, the idolatry of mathematical precision in legal reasoning, the idolatry of chauvinism, and the idolatry of degraded and unreasoning forms of patriotism and nationalism (as opposed to healthier versions).

Sandy's work is constituted by a fundamental ambivalence. He is opposed to idolatry, and yet he has sympathy and fascination with the signs and symbols of patriotism, nationhood, and law, including national monuments, and, particularly, flags. Anyone who knows Sandy knows how much he loves the American flag, and knows that he collects all sorts of different representations and uses of the flag, patriotic and critical, artistic and commercial. His collection of flags and representations of the flag symbolize the ambivalence that is inherent in his work, his love of the flag, the country, the nation, the people, and the Constitution, his admiration for how the flag can serve as a symbol of freedom, dissent and critique, and, at the same time, an almost anthropological fascination with how the flag has been used by people in ways that shock and horrify him. One of the most riveting examples in his large and impressive collection is a picture from a Nazi rally in 1939 held in New Jersey; the leader gives the Nazi salute in front of a display containing the American flag, the swastika, and Gilbert Stuart's portrait of George Washington. The combination of the flag as the symbol of American freedom, the iconic representation of Washington, the father of the nation, and the invocation of a deadly philosophy create fascination and horror in anyone who sees the picture.

18. Moreover, to say that the Constitution is a comedy, of course, is not to say that the path of progress will be smooth. Given the blood and struggle necessary to achieve justice, one may well wonder whether the game is worth the candle. And even if the Constitution becomes just over time, what comfort does this provide for those who suffer injustice and indignity in the present, before the moment of its redemption? Their mistreatment may never be fully recognized or rectified. If the Constitution is a comedy, it may be a very dark comedy indeed. 
Sandy and his wife Cynthia have lent a very large collection of pictures and representations of flags to the University of Texas School of Law, which are on public display in various areas of the law school. That collection, and its display in a school of law-devoted, as the entrance to the school tells us, to equal justice under law-cannot be understood on a simple level. The collection, and its placement in the law school, are both a celebration of American patriotism and a sly critique, both an advertisement of the law and a rebuke to the law. The pictures and works of art make conflicting statements, sometimes heartwarming, sometimes amusing, sometimes disturbing. That mixture, that ambivalence, that conflict, that frisson, is what Sandy's work is about. Through that conflict, that ambivalence, he hopes to expose the idolatry of others and avoid his own forms.

In a monotheistic religion like Judaism, Christianity, and Islam, one believes in God, and yet one knows that there are idols, graven images, false representations of the Divine. One adheres to words of the prophets and yet knows that there are false prophets. How do we tell the difference between the true image and the false, between the Word of God and the graven image? In some traditions, like Islam and Judaism, one avoids representations of the Divine altogether out of the fear of idolatry. Yet even if God himself is not pictured or represented, his teachings are. They must be, for religion to continue. The representation of the Word of God, the Will of God, the promise of the Divine remains, even if pictorial representations are banished. One must still ask how one tells the difference between the true representation of God's will and the false, the true connection to divine intelligence and the spurious. This is the problem of idolatry that remains after all the statutes have been smashed and all the pictorial representations of the Divine removed.

The problem is that one cannot always know the difference between the true and the false, the divine and the idolatrous. The idol does not tell you that it is only an idol of a nonexistent deity; the graven image does not tell you that it is merely a graven image. The false dogma does not reveal itself as false; the false prophet does not disclose his or her deception. All of them insist that they are true, and that you should believe in them, whether they are true or not. That is the danger, the problem of idolatry. It is a problem of faith. One must make a leap of faith in deciding what to believe and whom to believe, what customs to embrace, what institutions to follow.

The same problem occurs when we shift our attention from the Word of God to the law. Is our faith in law (or the Constitution) justified or misplaced, leading us to a certain form of idolatry? That is one reason why Sandy's work has long been concerned with the institution of chattel slavery, its importance in the formation of the American nation, and its effects on the development of the American Constitution. The constitutional law casebook that we edit with Paul Brest and Akhil Amar has long devoted more pages than any other to the constitutional problems of slavery. Antebellum America, and the antebellum Constitution that governed it, are the most powerful examples of a period in which — at least from our standpoint-Americans were engaged in idolatry, in the worship of a graven image. Americans worshiped law, freedom and democracy, but did so in a way that supported and justified great evils. It 
was a use of law, aggressively defended by its supporters in the name of private property, free enterprise, liberty, and democracy, that made a mockery of these concepts.

In contemporary America, we condemn this idolatry. We set ourselves against it. We define it as not us, not who we are. But we do not wholly succeed. For its effects are still with us. It is our birthright. It was placed at the foundation of our legal system, and even though the cornerstones have been removed, the impressions they leave still remain in the bones, the architecture of our Constitutional system, in the most unexpected ways: in the way we define what equality is, in the compromises between federal and state power that made the Constitution possible, even in the way that we elect our president through the use of an Electoral College. We have smashed the idols. We have cast them from the temple. And yet the spaces that the idols occupied are still there; the architectural decisions made to accommodate them still live with us today. A religion that smashes idols not only must fear that the idols will return, it must also live with the emptiness the idols leave in their stead, with their memory, with their remnants in the architecture of practice and belief. It is true of Judaism. It is true of Christianity and Islam. It is true, I would argue, also of law.

Yet law's encounter with slavery is not just a story of bad men doing bad things and disguising them under the forms and practices of law. Even during the antebellum period, the Rule of Law and the Constitution also served as a form of constraint-as a means of keeping the social and political order of the country together, as a means of dealing with difficult and terrible times. Even (or perhaps especially) in the antebellum Constitution, the Constitution of compromise, the Constitution of slaveholders, we can find utopian ideals.

One rarely faces the simple question whether to bow down to the idol that one knows to be an idol. One is never asked whether one should adhere to a false representation of the Divine Word, knowing it to be false. The idol never shows itself to us in that way, and the question of faith is never presented in so easy, or so stark a fashion. It is always more complicated than that. It is always uncertain what one has faith in. It is always uncertain whether one's faith will ultimately be vindicated.

Sandy's interest in presidential power and in what presidents do in the name of the Constitution is connected, I think, to his interest in the question of idolatry. His two favorite examples are Lincoln and Nixon, because of what both did in claiming to act on behalf of the Constitution, on behalf of the nation. Sandy is fascinated with Lincoln because Lincoln is the president who preserves the Union by denying civil liberties and by freeing the slaves. Both of these acts could be seen as violating the Constitution. ${ }^{19}$ In both cases, we might ask whether the suspension of habeas corpus, or the freeing of the slaves, is an act of faith in the nation, in the Constitution, in the Rule of Law, or whether it is a breach of that faith. History has elevated Lincoln to general regard as one of our greatest presidents. However, in Constitutional Faith, Sandy quotes a dialogue between David Frost and Nixon, in which Nixon defends his policies during the Watergate scandal in Lincolnian terms, arguing that if the President believes that his actions are

19. Justice Curtis argued at length that the Emancipation Proclamation was beyond the President's powers to conduct war and put down rebellion. Brest, Levinson, Balkin \& Amar, supra n. 15, at 226-28. 
necessary for the defense of the country, they are legal. ${ }^{20}$ When the president acts to save the country, he is not acting above the law. But of course, it's Nixon speaking, not Lincoln. When the words come out of Nixon's mouth, they seem far more troubling. After all, Abraham Lincoln is on the penny and the five dollar bill, and I don't think that Nixon ever will be. Juxtaposing Lincoln and Nixon, one might well ask, how do you tell, at the time of decision, at the moment of choice, which is the idol, and which is the true representation of God's word?

The dangers of apology and idolatry lead Sandy to a hermeneutics of suspicion in law, directed against the products of law, the claims of law, and the professional judgments of well-trained lawyers, schooled in the legal common sense of a particular historical period. The well-trained lawyer, devoted to the forms and practices of law, and professing a proud faith in both the Constitution and the Rule of Law, might nevertheless use the forms and devices, the rhetorics and mechanisms of law to perpetrate great injustices. The fact that lawyers are well-trained does not prevent these injustices. Instead, the injustices occur through the forms and devices, rhetorics and mechanisms of law. They are defended in the name of the Rule of Law, and those who dare speak against them are often accused of setting themselves against the Rule of Law, and, by definition, against civilization. Here again slavery is an apt example. The institution of slavery was supported and defended by the ablest legal minds of their time, who justified it as a sovereign right of states and as a sacred form of private property, and who drew upon their considerable talents to protect it, maintain it, and even expand it. If well-trained lawyers could have done this on behalf of slavery, what does this say about what equally well-trained lawyers might be doing today?

\section{LAWYERS, PRIESTS, AND RHETORS}

If we compare law to religion, who are the priests? The priests of law, one assumes, are lawyers and judges. If so, we might ask whether it is necessary to have faith in law, or in the system of legal authority, in order to be a good lawyer or a good judge. Moreover, we might ask whether a professor of law must profess faith in law in the same way that we might expect a professor in a divinity school or a school of theology to be a believer devoted to promoting the faith and to training new clerics similarly imbued. In Constitutional Faith, Sandy asks whether the law school is best compared to a department of theology or a department of religion. The purpose of the former is to teach the truths of religion; the purpose of the latter is to search for truths about religion. A professor in a religious studies department does not have to believe in a particular religion. Some members of the faculty might even be atheists or agnostics, because to be a member of a religion department one might only be interested in religion from an anthropological, sociological, historical, or economic standpoint. By contrast, a

20. Levinson, supra n. 3, at 133 n. *. Sandy points out that Lincoln, unlike Nixon, added the proviso that if the people do not agree with the President's decisions, they can vote him out of office. Id. at 133 . But he adds that the difference may not be so great: if Nixon had persuaded the public that his actions were necessary, history might well have treated him more kindly. Hence "it is necessary to ask whether Nixon's offense was his disobedience to law, or his patent failure to persuade the public that his violations of law were truly required to protect "national security." Id. at 133-34. 
department of theology would presumably restrict its membership to those who genuinely believe. ${ }^{21}$ If law professors train lawyers, who will represent clients, does this mean that law professors have to have faith in law? Or does it mean only that they have to be skilled in teaching their students what they need to know to be effective adversaries and represent their clients effectively in the existing legal system?

This last question suggests that there might be an important distinction between lawyers and priests. Lawyers are rhetors who manipulate and wield rhetoric in order to persuade others and to promote the interests of their clients. Priests, on the other hand, are expected to believe in what they say to those they lead and to those they seek to convert. Yet on closer inspection, the distinction between lawyers and priests is not as great as might be supposed. There is, after all, a long tradition of preaching and of the study of preaching in the history of religion. The purpose of preaching is to persuade, convince, move, impel, and convert the audience, bringing them closer, one hopes, toward goodness, toward faith, toward God. But the same techniques that one studies in learning how to move the audience emotionally and bring them closer to what is good are the same tools that might be used to move the audience toward perfidy, and encourage them to do all sorts of terrible things. Both the cause of abolition and the defense of slavery were preached from pulpits in antebellum America, and the history of religion is strewn with examples of false prophets and demagogues who exhorted their flocks to intolerance, injustice, and violence, all in God's name. In this sense, the problem of the lawyer as rhetor is also a problem for the preacher. The rhetorical skills of both the lawyer and the preacher might lead others to idolatry and apology.

To be sure, the problem seems particularly urgent in the case of lawyers. After all, lawyers are hired to say things they don't necessarily believe. They may in fact believe them, or come to believe them through repeated argument, but they don't have to believe them as long as what they say benefits their clients. Saying things they don't believe, massaging the facts, stretching the truth, offering contrary perspectives, sowing doubt, and proliferating confusion is what lawyers do for a living. One can certainly offer reasons why lawyers' role as rhetors is entirely consistent with the Rule of Law and actually promotes the justice of the legal system in the long run. The adversary system, one might point out, is the best device for weighing competing claims, working out the practical meaning of abstract legal principles, and settling disputes. In this way, lawyers' role as wielders of rhetoric lets the law work itself pure and helps the law perform its function of avoiding violence and securing peace. That is how one might reconcile the vision of the lawyer as rhetor with one's faith that the Rule of Law (or the Constitution) will be a comedy and not a tragedy; that one's faith in law, or the Constitution, ultimately will be vindicated. One can certainly argue in this fashion, but it takes considerable effort, for the claim is not obvious on its face. It takes - dare one say itsome degree of faith: faith in lawyers and in the system of legal argument and legal contestation.

If lawyers are rhetors who sometimes say things they do not believe, are there no constraints on the practice of legal argument? Or do some forms of rhetoric breach the

21. See Levinson, supra n. 3, at 157-161. 
faith that lawyers owe the system of law? This brings us to problem of frivolous legal argument, which is, not coincidentally, the subject of Sandy's essay, Frivolous Cases, subtitled, Do Lawyers Really Know Anything at All ${ }^{22}$ Sandy's fascination with frivolous legal argument is itself hardly frivolous. It is connected to many of the themes outlined above: the lawyer as rhetor who is nevertheless a key player in maintaining a system of faith in the Rule of Law, the relationship between the Rule of Law and justice, and the question whether the story of law (or the Constitution) is ultimately a comedy or a tragedy.

Frivolous legal argument marks a liminal point in a system of law premised on faith in the Rule of Law and its ultimate vindication. If no legal arguments can be dismissed as frivolous, then law cannot constrain arbitrary power, and all manner of evils may be done in its name. Hence, the boundary that separates the frivolous from the nonfrivolous must be preserved in order to preserve the possibility of faith in law. Because of its importance in sustaining faith in the Rule of Law, the boundary between the frivolous and the serious must be guarded, and guarded jealously. It follows that the lawyer who makes a frivolous legal argument has done more than make a mistake; he or she has breached a crucial boundary that undergirds the system of legal faith and faith in the legal system. But the problem is that sometimes it is very hard to tell what the boundaries of frivolous legal argument and nonfrivolous legal argument are, or as I like to put it, what is "off the wall" and what is "on the wall."

The practice of legal argument, and perhaps equally important, the practice of politics, can shift the boundaries of what is on the wall and off the wall. The boundary that demarcates the frivolous from the plausible but wrong can be moved, and it is and has been continuously in motion. It is moved through repeated assertion and argument by well-trained lawyers in legal cases, and it is moved through assertion and protest in politics. There is perhaps no better example of this than the famous case of Bush v. Gore. $^{23}$ Prior to November 7, 2000, the legal arguments made by the Bush forces concerning the meaning of Article II, Section 1, and the Fourteenth Amendment's Equal Protection Clause would have been regarded by most lawyers and judges as off the wall. $^{24}$ But within a short space of time, a number of very important and influential people got behind these arguments, including Theodore Olsen, a seasoned Supreme Court litigator who is now Solicitor General of the United States, and a respectable number of conservative legal thinkers, including at least two members of the Harvard Law faculty. ${ }^{25}$ Perhaps most importantly, several members of the United States Supreme Court thought that these arguments were not only plausible but convincing.

22. Sanford Levinson, Frivolous Cases: Do Lawyers Really Know Anything at All?, 24 Osgoode Hall L.J. 353 (1986).

23. 531 U.S. 98 (2000) (“Bush II”).

24. See Michael J. Klarman, Bush v. Gore Through the Lens of Constitutional History, 89 Cal. L. Rev. 1721, 1731 n. 45, 1730-31, 1736-37 (2001).

25. See Einer Elhauge, Bush v. Florida, N.Y. Times A27 (Nov. 20, 2000) (arguing that manual counts had no objective and clear standards, thus anticipating the equal protection argument made in Bush v. Gore); Chalres Fried, "A Badly Flawed Election,": An Exchange, N.Y. Rev. Books (Feb. 20, 2001) (defending the result on Article II, Section 1 grounds). 
In law, authority matters a great deal in determining plausibility, and the plausibility of a legal argument is often shaped by powerful and influential people who are willing to stand up and stake their reputations as reasonable people on making the argument or defending it. In this way, authority reshapes the boundaries of the plausible and the implausible. ${ }^{26}$ After Bush v. Gore, for example, arguments that were once off the wall are off the wall no longer. Some of them, in fact, are the law of the land.

Obviously, this has implications for the problem of legal faith. The boundary that separates the plausible from the implausible, the off the wall from the on the wall, is the boundary that helps preserve faith in the law and the legal system. It is the boundary that distinguishes the Rule of Law from the arbitrary exercise of power. But if that boundary is not fixed, but moveable, and if that boundary can be moved through politics, or through the assertions of powerful people who seek to maintain their power, the certainty of our faith in law might well be shaken. If the rich and the mighty can increase their power by turning bad legal arguments into good ones through the force of their influence, what is the point of belief in law as a constraint on power? It would be as if the church modified its doctrines to benefit the rich and altered its understanding of Divine revelation to accommodate the interests of powerful. This, indeed, has probably happened more than once in the history of religion, but that fact hardly excuses the practice. Indeed, it shakes our faith all the more.

It would perhaps be simpler if the boundaries of the plausible and implausible were truly fixed, subject only to depredations by the powerful. Then one could simply criticize the powerful for disturbing the purity of law and undermining legal faith. But the problem is larger than this. The law is a historical product, shaped through evolving conventions. No transhistorical set of criteria defines what is on the wall and what is off the wall in legal argument. At any point in time, some arguments are clearly frivolous, but the class of such arguments keeps changing, and it changes in part through the very activity of making arguments that skirt the boundaries of the implausible and off the wall.

Knowledge of history and of historical change challenge the simplest forms of faith in law, just as they challenge the simplest forms of religious faith. To be a Jew today is not to believe in or to practice the same exact things Jews believed and did in the past. The destruction of the Second Temple, and the Diaspora that followed it, set in motion events that fundamentally and profoundly changed Jewish identity and Jewish faith. So, too, did modernity and the Enlightenment, and so, too, did the Second World War, the Holocaust, and the creation of the State of Israel. To be a Jew means maintaining connection to that changing tradition. It means being able to have faith despite the fact of these changes, or more correctly, to have faith through the fact of these changes. But such a cosmopolitan, historicist attitude creates great dangers if one is also committed to avoiding idolatry. For if the Word of God is not fixed, but continually changes, if the meaning of Divine Revelation is made in history, and altered by moral human beings, how do we tell the false prophets from the true ones? How do

26. See Jack M. Balkin, Bush v. Gore and the Boundary Between Law and Politics, 110 Yale L.J. 1407 (2001). 
we tell the genuine representation of Divine law from idolatry? Or to put the problem another way, if the history of the Jewish people were different, and the political pressures put upon them were different, would the content of the Torah and of Jewish law also be different? And if they would be different, would they equally be the Word of God? Can religious faith, or legal faith for that matter, survive the acknowledgment of change, of politics, of contingency?

\section{LAW AS PERformance}

Another way to consider the relationship between lawyers, judges, and faith in the Rule of Law, or in the Constitution, is through the lens of performance. Sandy and I have argued that a fruitful way to think about law is through an analogy to the performing arts, in particular music and drama. ${ }^{27}$ The law and literature movement famously argued for an analogy between legal interpretation and the interpretation of poems, novels, and literary texts. Sandy, of course, was one of the key figures of the law and literature movement during its beginnings in the 1980s, and his 1982 essay, Law as Literature, was an important document in the early history of that movement. ${ }^{28}$ But it is characteristic of Sandy's devotion to intellectual exploration that he moved past that early theoretical comparison, and arrived at a much more interesting and complicated position. The proper analogy, he and I have argued, is not law as literature, but law as music or drama. Rather than thinking about what lawyers and judges do through the lens of interpretation, like a poem, or a novel, one should think instead of the work of lawyers and judges as performances before an audience. We should regard law as a performing art, as something that must be performed in order to be brought into being and have effects in the world.

The analogy of law to literature suggests that the judge's relationship to the author of a legal text is like the reader's relationship to the author of a literary text; the question is what it means to interpret the text correctly, or faithfully, or otherwise appropriately given the existing conventions of interpretation. However, when we think about law in terms of performance, it is immediately obvious that the performer has a double relationship: to the author or composer of the text, and to the audience or community before whom the performance takes place. There is a duty of fidelity and responsiveness both to the author or composer, and to the audience or the community in which one performs. These relationships and responsibilities can push the performer in the same direction, or they can tug in different directions, creating important tensions and producing important opportunities for interpretive adaptation and creativity.

The triangle of performance - consisting of author, performer, and audience - puts the question of faith in a different light. Faith is not simply a question of belief in the law or the Constitution; it is a duty of fidelity or faithfulness to both the author and the audience. Performers must not betray the text, but they must also not betray their audiences. Fidelity and faith, of course, are interrelated. Fidelity requires faith in what

27. Sanford Levinson \& J.M. Balkin, Law, Music, and Other Performing Arts, 139 U. Pa. L. Rev. 1597 (1991); J.M. Balkin \& Sanford Levinson, Interpreting Law and Music: Performance Notes on "The Banjo Serenader" and "The Lying Crowd of Jews," 20 Cardozo L. Rev. 1513 (1999).

28. Sanford Levinson, Law as Literature, 60 Tex. L. Rev. 373 (1982). 
one is faithful to; it is precisely when one loses faith - in a marriage, in a Constitution, in a system of law - that one strays from it, trying to obtain something better. So it is not simply that the performer must not betray the text or the audience; the performer must also believe in them-believe in their goodness, their openness, their receptivity, their adaptability to new situations and new conditions. The performer must believe that what he or she performs can speak to the audience of today and its concerns, and, equally important, that the audience-some audience, at any rate-is prepared to listen and respond. Otherwise, there is no point performing a text, or performing it before an audience. Without faith in the text, one is not performing it; one is criticizing it or modifying it. Without faith in the audience, one is not performing before the audience; one is berating it or mocking it.

There is a deep connection, then, between interpretation and faith, and it appears at all three points of the triangle of performance. Recall our earlier discussion: When we say we have faith in the Constitution, do we mean only that we have faith in a text, the work of the founders and framers of the Constitution? Or do we mean that we also have faith in the American people, the American nation, and their ability to redeem themselves from previous inequities and progress toward an ever freer and more just social order? The view that the Constitution is ultimately a comedy, which, as we have seen, is also a statement of faith, is a statement of faith not only in the text of the Constitution, not only in the work of judges, but also in the Constitution's "audience," if you will-the American people themselves. We cannot understand constitutional faith without understanding this fact.

This triangle of performance-between the composer, the performer, and the audience or community - is the missing dimension in the standard account of the analogy between law and literature. While it is certainly true that there can be no performance without texts to perform, there can also be no performance without audiences in front of whom one performs. Even poetry, after all, can be performed before an audience, and the oldest poems - the great oral epics of antiquity - were meant to be performed. Sometimes, indeed, there was no clear author-the epic poem was the work of many hands - but there always was an audience to entertain, amuse and instruct, an audience before whom the work had to be brought to life.

The tug on the performer from the text and the audience-or audiences, for there may be many different audiences and subaudiences for a particular performance-is the creative tension that produces good or bad interpretations of a work. There is a give and take between the performing artist and the composer-between the composer whose artistic vision must be respected, whose text the artist must obey, and the artist whose imaginative genius must be allowed to express itself. But there is also a give and take between performers and their audiences. We must also attend to the interplay between the audience, the community, the flock, the faithful, on the one hand, and the lawyer, the performer, the rhetor, the preacher, on the other. If we do not attend to this interaction, we cannot understand how law changes and develops. We may think that the creative genius of the performer is the engine of change in interpretation, but that is really only half the story. It is the audience or audiences whom the rhetor, performer, lawyer, or preacher always confronts. It is the audience or audiences whom he or she must delight, 
satisfy, entertain, instruct, edify, move, govern, organize, and inspire; they are the great unacknowledged engines of change in interpretation. The audience is not a passive receptacle for the performer's creative sallies; it is not simply a blank slate sitting in the darkness of the theater waiting to be shocked or amused. Members of the audience may have their own opinions about good and bad performance, and they may become their own performers, offering their own interpretations of the work that will affect how the performer performs. Performers always demand that audiences pay attention to them and to their genius. But sometimes it is the audience to whom attention must be paid.

\section{CATHOLICISM AND PROTESTANTISM}

The presence of multiple and contrasting views about interpretation leads inevitably to the question of authority - the question of whose interpretations control. In the world of faith, it is captured in the dispute between heterodoxy and orthodoxy. The term "orthodoxy" arose at a particular point in the history of the Christian church to mark those beliefs officially adopted by the church - the orthodox, which literally means "straight belief" - and to dismiss the wide variety of beliefs that did not so conform - the heterodox, which means "other belief." But the very attempt to describe one's beliefs as orthodox and one's opponents as heterodox, and to condemn those different beliefs as heresy, recognizes the fact of a plurality of beliefs even as it casts them out. Every religion must face the question of whether there is one true faith, or whether there might be multiple, different faiths, each of which could rightfully claim that they were the true faith, true belief in God. The description of one faith as the true faith obliquely admits the very thing it wishes to deny-the possibility of several faiths, several paths to God. The fact that those with heretical faiths believe cannot be denied; one can only insist that they believe wrongly, and that their beliefs will lead them to perdition.

There is an analogous problem in law: interpretations of the law proliferate over time, so one must face the question whether there is one true, correct interpretation of the law, or whether there are multiple interpretations of the law, each of which could be true or correct, and all of which are law, in some important sense of the word. The question is whether and to what extent law requires a final determination of its meaning by some institution that has the final authority to say what the law is, and to declare contrary interpretations wrong and actions based on them illegal or, at the very least, not required by law.

This brings us to Sandy's famous distinction between constitutional catholicism and constitutional protestantism. When Sandy offered this distinction in Constitutional Faith, he gave it two different dimensions. First, Sandy drew a distinction between those who believed that in interpreting a text, like the Bible or the Constitution, one must look to sola scriptura, to the text alone, and those who believed that one must take into account other modalities of interpretation, ${ }^{29}$ as Philip Bobbitt calls them. These modalities might include (for example) history or consequences. ${ }^{30}$ Second, Sandy

29. Levinson, supra n. 3, at 18-22.

30. Philip Bobbitt, Constitutional Interpretation (Blackwell 1991); Philip Bobbitt, Constitutional Fate: Theory of the Constitution (Oxford U. Press 1982). See J.M. Balkin \& Sanford Levinson, Constitutional Grammar, 72 U. Tex. L. Rev. 1771 (1994). 
offered a distinction between those who believed that there should be a single, central source of authority about the meaning of religion, faith, theology, dogma, law, or the Constitution, and those who believed that interpretation should be left up to the conscience of the individual believer. ${ }^{31}$ Under this view, interpretive "catholics" look to a central source of interpretive authority-for example, the United States Supreme Court's interpretation of the Constitution, while interpretive "protestants" might recognize the authority of the political branches, social movements, and even individual citizens to interpret the Constitution. ${ }^{32}$

Of the two axes or dimensions of Sandy's distinction between catholicism and protestantism, the second one has proven more fertile in the subsequent literature, while the first has largely been forgotten. There are two reasons for this. First, the modalities and styles of constitutional argument and constitutional interpretation are multiple, not unitary. People do not look only to the text to tell them what the Constitution means, they also look to history, to governmental structure, to precedent, to consequences, to natural law, and to the ethos of America as a nation. Second, by contrast, the question whether the Supreme Court has the final say in the determination of the Constitution's meaning is an ongoing controversy. That controversy has been spurred on in recent years by the work of the Rehnquist Court, which has taken a decidedly judicial supremacist line in promoting its conservative political agenda. Sandy's articulation of constitutional protestantism has struck a sympathetic chord with constitutional thinkers who are critical of judicial supremacy and judicial review, and who seek to discover alternative constitutional values in the work of legislatures, executive officials, social movements, and ordinary citizens. Constitutional protestantism, which celebrates individual conscience and constitutional values that arise from the bottom up, seems an altogether useful corrective to constitutional catholicism, which, in the hands of the current Supreme Court, at least, insists on a unitary meaning of the Constitution that comes from the top down.

In Constitutional Faith, Sandy treated catholicism and protestantism as ideal types, representing an opposition between individual conscience and institutional authority. In fact, I believe that they form a nested opposition, for in practice each incorporates elements of the other and depends on the other. ${ }^{33}$ This interrelation is hidden when we think about the Constitution statically. It becomes apparent when we view the Constitution as a dynamic system. The views of courts are not fixed; they change over time in response to changing political circumstances, and, in particular, to the constitutional views of social movements and political parties. Many changes in constitutional doctrine do not occur simply because judges happen to change their minds; they occur because people with particular constitutional views organize to promote those views and, if successful, eventually influence the sorts of people who are appointed to be judges and Justices.

\footnotetext{
31. Levinson, supra n. 3, at 23-27.

32. Id. at 27-30.

33. See J.M. Balkin, Nested Oppositions, 99 Yale L.J. 1669 (1990) (reviewing John M. Ellis, Against Deconstruction (Princeton U. Press 1989)).
} 
Despite the Supreme Court's pronouncements, we live, as we always have, in a world of constitutional dissensus - a world in which lots of people believe that the Supreme Court has gotten it wrong, and that their view is the right one. These people gather, and form social movements; they influence political parties or take them over. Eventually some of them change the norms of society, and they succeed in appointing judges and Justices who interpret the Constitution in new and different ways. In this way, constitutional catholicism, a top-down approach that asserts a single authoritative source that determines constitutional meaning, secretly depends on constitutional protestantism, a bottom-up approach that emphasizes the wide variety of dissenting views about the Constitution held by people who struggle to persuade others about the truth of those views. When we think about the Constitution dynamically, it becomes clear that dissensus about constitutional values - the most characteristic feature of constitutional protestantism - is the great engine of constitutional change, shaping even that most "catholic" of institutions, the United States Supreme Court.

Conversely, in explaining how the dissenting views of individuals eventually succeed in changing constitutional doctrine, we will discover the "catholic" elements in constitutional protestantism. Although constitutional protestantism exalts the individual conscience and the individual's interpretation of the Constitution, constitutional protestants succeed in influencing constitutional politics because they attempt to persuade others to their views and successfully take over the institutions of interpretive authority associated with constitutional catholicism. The revolution in understandings of federal power that we identify with the New Deal were cemented not in 1937, the year of the Court's fabled "switch-in-time," but in the years immediately after, when President Franklin Roosevelt and an overwhelmingly Democratic Senate were able to replace the conservative jurists that had hindered his New Deal programs with advocates of expanded federal power. The constitutional dissenters had captured the temple of justice and made it their own. In like fashion, movement conservatives in our own day have fought a thirty-year battle to undo the work of the Warren Court and stock the federal judiciary with like minded individuals. As Sandy and I have recounted, they have in many respects succeeded, and are now on the verge of major transformations in constitutional meaning. ${ }^{34}$

Constitutional protestantism celebrates dissent from institutional authority, but it is important to recognize that dissenters do more than have beliefs. They also try to convince others that these views are correct. Their ability to do so depends on their organizing themselves into social movements and political parties and pressing their claims on judges and government officials, and, if these judges and officials will not listen to them, winning elections and replacing those judges and those officials with ones more to their liking. The power of constitutional protestantism, in practice, is exercised through the political process, through the party system, and through judicial appointments which are controlled by the major political parties. If one wants one's views of the Constitution to become widespread and accepted, one must organize, one

34. See Jack M. Balkin \& Sanford Levinson, Understanding the Constitutional Revolution, 87 Va. L. Rev. $1045(2001)$. 
must form political communities of belief, create new doctrines and dogmas, and attempt to gain control of the levers of institutional authority, including not only the Congress and the presidency, but also the courts. That, of course, is what successful social movements have done throughout American history. Their views about the Constitution won out because they went out into the world searching for converts, persuading, displacing, and replacing those with a contrary viewpoint.

When Sandy offered his original distinction, he did not focus on these institutional features of protestantism. He was more concerned with what I have called the problem of idolatry. ${ }^{35}$ Constitutional protestantism is a rebuke to idolatry. It insists that each of us has the opportunity and the responsibility to decide what the Constitution means, and to decide whether public officials - including members of the Supreme Court-have been faithful to that meaning. Constitutional protestantism asserts faith in something beyond positive law and the practices of government officials. It imagines an ideal Constitution that has yet to be realized. Through faith in this Constitution, one avoids idolatry, one refuses to bow down to a false image of our higher law. One may have to obey positive law for practical reasons, but one still retains belief in a Constitution-the real Constitution - that is not determined by those who control it momentarily.

This romantic conception of protestantism focuses on individuals, not on collectivities, and on the power of individual conscience. But in practice, in lived history, constitutional protestantism is not simply a privilege of conscience. It is a structural feature of the system of constitutional democracy and of constitutional change. Constitutional change occurs because people have different views about what the Constitution means and they organize in groups to try to convince others that their views are correct. This task of organization and persuasion has an entirely apt analogy in religion: it is the work of proselytization and conversion. Thus, even if constitutional protestantism begins with the conscience of the individual believer, it will not long remain so. For the history of protestantism itself is the history not of isolated individuals, but of communities of belief, reaching out continuously to convert others and bring them to the truth.

Through political parties and social movement activism, constitutional protestants dissatisfied with the pronouncements of the legal equivalent of the Papacy-the Supreme Court of the United States - not only can change the public's views of what the Constitution means, they can also change the meaning ascribed by the courts themselves. Sometimes their attempts at change are successful, and sometimes they are not. But the engine of Constitutional change is protestantism and proselytization.

One might object that my redefinition of protestantism as the engine of constitutional change obscures the real question: the question of authority. Constitutional catholics might concede that constitutional change occurs in much the way I have described, and yet insist that this tells us nothing about who possesses legal authority to interpret the Constitution. The work of social movements and political parties is interesting from the standpoint of political analysis, but this analysis does not

35. See Levinson, supra n. 3, at 88 ("Nor ... can constitutional faith be regarded as anything other than idolatrous if it leads its adherents to suspend their independent evaluation of the tenets of the faith."). 
demonstrate that legal authority is vested in those who disagree with the Court. That authority, a constitutional catholic might insist, is vested in the Supreme Court of the United States and the lower courts, at least with respect to a very large share of constitutional questions that lie outside of the realm of foreign policy. If Constitutional protestantism is not claiming that political actors and social movements have legal authority to interpret the Constitution, then it is merely a description of politics. If it does make such a claim of legal authority, it is untenable. It is one thing to say that the National Rifle Association ("NRA") disagrees with the Court about whether the Second Amendment protects an individual's right to bear arms and that it tries to persuade others to its way of thinking and attempts to influence the judicial selection process. It is quite another to say that the NRA has the authority to determine the meaning of the Constitution.

And yet, I think that this objection fails to take seriously the issues at stake. By reducing constitutional protestantism to a normative claim about legal authority, one tends to miss the big picture. That big picture is a story not about what constitutes authority at a single moment in time, but how legal authority is produced over time. What is important is not whether constitutional protestantism or catholicism is a normatively correct statement of authority at a particular point in time, but the dialectic between the authoritative pronouncements of courts and the assertions of constitutional norms by those outside the courts. Constitutional protestantism, I would insist, is important not as a static claim of legal right, but as a dynamic feature of the constitutional system. The authority with which constitutional protestantism is concerned is the democratic authority that eventually turns claims of political principle into positive law, the constitutional alchemy that spins the gold of legal norms out of the straw of political contestation. Constitutional change is produced by the very thing that constitutional protestantism describes: the fact that people have different beliefs about what the Constitution means, the fact that they struggle over those contested meanings, and the fact that some of these meanings, and not others, win out, and become enshrined, for a time, in the positive law of the American Constitution. The question of whether one believes in constitutional protestantism is like the old joke about baptism: I not only believe in it, I've seen it done.

Authority is produced historically. Law changes, standards of legal judgment change, the conditions of constitutional plausibility change. To understand authority, we must understand how authority changes. To understand how authority changes, we must understand the engines of change. Asking the normative question, "Does the Supreme Court have the right, or does an individual have the right to have their view of the Constitution be law?" already skews the debate, for it misses the historical and dynamic elements in how authority is constructed. By reducing the debate between constitutional catholicism and protestantism to a simple normative question about who has authority, one makes it impossible to discuss the mechanisms of constitutional change that produce authority.

We might recast this point in larger jurisprudential terms. The notion of constitutional protestantism is, I would submit, more than a theory of constitutional interpretation, or even a theory of constitutional change. It is also a deeply subversive 
theory about what "law" is. Constitutional protestantism offers a theory of what one might call, to coin a phrase, the "constitutional demi-monde." At any point in time, whether or not actually recognized by judges, there is constitutional "law"- the quotation marks are completely appropriate here - circulating around the country. This "law" consists of claims about constitutional values and norms, claims such as "Slavery is unconstitutional," said by someone before the Thirteenth Amendment, or "Women have the right to vote," spoken during the 1870 s, or, "The Constitution forbids segregated public schools," spoken in 1945, or “'Don't Ask Don't Tell' is unconstitutional," spoken today. Such claims about the Constitution do not qualify as law in the ordinary sense, because they are not the opinions of those legal officials authorized to pronounce what the law is. But neither are they simply political or policy claims. They are claims of law made about the law, and they are part of the process of constitutional lawmaking and law changing. And the process of making protestant constitutional claims - constitutional claims as yet unrecognized by courts-is an essential feature of the system of constitutional lawmaking in the United States. So in that respect, it is paradoxically part of official lawmaking, even if not officially recognized as such. That is why I speak of the constitutional demi-monde, because these constitutional claims are neither fish nor fowl; they are neither purely political claims nor the sort of legal claims recognized by legal authorities. The practice of constitutional claiming, of constitutional norm assertion and formation, is the sort of thing designed to give an analytical legal philosopher fits. And yet, the idea of a constitutional demimonde, a veritable sargasso of constitutional claims from which new constitutional norms emerge, follows rather easily from the idea of constitutional protestantism, and the dialectic between constitutional protestantism and constitutional catholicism that I have tried to outline in this essay. It is a thicker, more interesting, and more puzzling conception of law and lawmaking. It is a theory of law as performance, a theory of law as demi-monde, a theory of legal change, and it all flows out of the rich, fertile soil of the distinction that Sandy first offered in Constitutional Faith.

\section{HERE ENDETH THE LESSON}

What is faith? Faith may be faith in a thing outside the self, but inevitably it is also faith in one's self and in one's relationship to the object of faith. One may have faith in a text, but the contours of that faith are ultimately defined by one's relation to other human beings. What is idolatry? Idolatry is faith in what one ought not to have faith in. But to reject idolatry requires faith of a different sort. For one smashes idols to re-assert faith in the true. Yet if all of the gods are idols, it matters not which one believes in, or whether one believes at all.

Faith in law always risks idolatry, for law is made by fallible human beings. Appeal to Divine law does not save us from this problem, for even God's own laws are known only through the arguments and beliefs of mortals. Christianity, and particularly protestant Christianity, famously criticized Judaism and its covenant with God because adherence to God's law is too difficult for sinful human beings to live up to. The problem, however, does not lie simply in our inability to live up to God's law. It also lies in our inability to know what that law is. Human representations of God's will 
inevitably become corrupted by parochialism, self-interest, and short-sightedness. In this way, righteousness turns into reaction, piousness into hypocrisy. How much more so is this true of law that makes no claims to Divine authority? And yet, for all that, one still must have something in which to believe.

Lawyers are merchants of faith: they trade on faith, they trade in faith. Without law, they tell us, there can be no justice; with law, justice is at least possible. Law offers us the promise of justice without ever making good on that promise in full. That is why the most basic problem of jurisprudence is the problem of faith in law; and the most basic question in jurisprudence is the question to what extent our faith in law is justified. At the heart of law, and the philosophy of law, lies the problem of faith and idolatry.

That is what Sandy Levinson taught me. 